\title{
"Engaging Men and Boys" to Prevent Male Violence against Women in Turkey: Community Mobilization Approach
}

\author{
Assist. Prof. Filiz YILDIRIM ${ }^{1}$ \\ ${ }^{1}$ Ankara University, Faculty of Health Sciences, Department of Social Work
}

\begin{abstract}
Male violence against women, observed within the family or outside the family, in every country regardless of its development level has become one of the most prominent social problems Turkey is trying to deal with. No matter in which group they are from, women in Turkey from almost all groups are under the risk of violence irrespective of their education and economic status, age, marital status or the region they live. It is not only the women who are exposed to violence but also men who resort to violence, their families and the whole community are affected negatively by the violence. More alarming is that some of the women exposed to violence are unable to demand help from anywhere and some are even thinking of committing suicide due to the violence. For these reasons, preventing male violence against women is required to be seen as an important and urgent necessity in Turkey.

In this study, engaging men and boys is focused in order to prevent male violence against women in Turkey and "community mobilization approach" is based on as a perspective. Furthermore, it is explained why this approach is based on to prevent violence. In the framework of this approach, suggestions are presented on the responsibilities men could take considering the factors causing men to resort to violence against women in Turkey.
\end{abstract}

Key Words: Woman, male violence, community mobilization

\section{Introduction}

Male violence against women, observed within the family or outside the family [1,2], in every country regardless of its development level has become one of the most prominent social problems Turkey is trying to deal with. Recent studies $[3,2]$ have indicated that women are exposed to violence more by their partners (such as husbands, boyfriends or fiance). In these studies, the percentage of the women who had been exposed to a kind of emotional violence in some point in their lives (44\%) was higher than that of those who had been exposed to emotional violence in the previous 12 months (26\%). Moreover, the ratio of married women who stated that they had been exposed to physical violence was 36\%. In other words, almost 4 out of 10 women stated that they had been exposed to their partners' physical violence. Furthermore, the ratio of the women who had been exposed to a kind of physical violence in the previous 12 months was $8 \%$. While $19 \%$ of those women stated that they had been exposed to medium-scale violence, $16 \%$ of them stated that they had been exposed to severe violence including other violent behaviours (such as emotional or economic violence). In addition, in the same study [2], it was determined that a considerable number of women had been exposed to economic (30\%) and sexual violence (12\%). Moreover, the study [2] showed that women had been exposed to violence after their 15 years of age by their fathers, brothers or male relatives (brother-in-law or father-in-law) or boyfriends in addition to their partners. When considered that this study was conducted in 2014, it can be claimed that male violence against women in Turkey persists in significant levels. What is more, another study (4) has indicated that women are exposed to violence even by the men in the street.

Women in Turkey sustain damages from the results of the physical, emotional, sexual and economic violence subjected almost always by men. The outcomes of being subjected to violence for women could present themselves as physical harm, dismissals from the working places, enforced sexual intercourse or oppression by frightening [3,2]. Additionally, violence could lead women to feel unhappy and even to thinking of committing suicide. According to a study [3] conducted all across Turkey, a significant correlation exists between being subjected to violence and the presence of indicators of some physical and emotional health problems (feeling unhappy and presence of will to commit suicide). It was detected that the negative evaluation of self health status among women exposed to violence was two-three fold when compared to women not exposed to any violence 
regardless of region where they live or their basic features. In a study conducted by Ozyurt and Deveci [2010] in rural regions, the depressive symptom risks among women who had pre-diagnosed psychological illnesses and a suicide history and who had been exposed to violence during their marriages determined to be high [5].

Some studies have demonstrated that it is not only the women who are exposed to violence but also men who resort to violence, children, other members of the family and the whole community are affected negatively by the violence $[6,2]$. For this reason, preventing male violence against women is required to be seen as an important and urgent necessity in Turkey for the well being of not only the women subjected to violence but also of the men who resort to violence and the children who are witnessed to it as well as the whole community. Engaging men and boys in the prevention attempts as well as women is an important necessity.

In this study, engaging men and boys is focused in order to prevent male violence against women in Turkey and "community mobilization approach" is based on as a perspective. Furthermore, it is explained why this approach is based on to prevent violence. In the framework of this approach, suggestions are presented on the responsibilities men could take considering the factors causing men to resort to violence against women in Turkey.

\section{Mobilizing Community to Prevent Male Violence against Woman}

Call for global action has been made in order to engage men in the prevention attempts for the male violence against women all over the world [7]. One of the approaches is "Community Mobilization Approach", which was tried in many countries such as Brazil [8], and Uganda [9] in order to prevent violence against women, which provides evidence-base and, which is also used to attract attention to health, social or other environmental problems [10].

Community mobilization approach attempts to reach individuals, relationships, communities, and the larger society to support the antiviolence organization and to address male violence against women [11, 12]. As Michau (2007) stated, "community mobilization adds up individual interventions, sequences them into a logical progression, strives to build on what is achieved, and has an overview on how various activities will slowly come together to change the social climate. It is responsive, participatory and based on a holistic analysis of the root cause of violence against women" [13, p. 97]. It is claimed that this approach is effective in preventing male violence since it considers lower status of the women, underlines the power unbalance between women and male and points out the fact that the main reason behind the male violence is rigid gender roles. In addition, in this approach, a holistic point of view is presented taking also into consideration the complex history, culture and interactions of the society in which the male violence manifests itself. Moreover, it is focused on the idea that a social transformation period is needed in the community in which violence is observed in order to prevent male violence against women. In the framework of this approach, which is also based on human rights [12], Ecological Model [14] is resorted to mobilise the society to prevent male violence. Heise [1998] who has developed this model, conceptualizes violence as a multifaceted phenomenon grounded in interplay among individual, relationship, community, and societal levels as spheres of influence [14]. In the mobilizing the society, the risk factors leading to male violence are analysed considering these four different spheres of influence and preventive strategies are planned [15]. This model is prominent since it focuses both on ways of enabling changes in the behavioural patterns which legitimize male violence in the society and on the necessity that each individual from every level [individual community members and leaders, the institutions like health, governance, security, education, the bodies that influence policy or social climate (media, law makers, donors, etc.)], female and male together, should take role in the attempts to prevent male violence in the society [16].

As can be observed in the outcomes of one of the studies [2] conducted all across Turkey, the fact that women do not inform authorities most of the time regarding the violence they are subjected to and that they do not even inform close-relatives show how essential it is to consider a multi-dimensional evaluation in the scope of this approach. In this study [2], major reasons given by women for not informing the authorities about violence were not seeing violence as a serious problem, love to person whom they are with, forgiveness, or their beliefs that he will change, their embarrassment to be publicised or fear of being labelled. Furthermore, they stated that their fear that their children would be unhappy or that they would lose their children after a separation from the partner, and not knowing where to apply for were effective on why they had not informed the authorities about the violence. Keeping this example in mind, many factors discouraging women from informing the authorities about the violence they are exposed to should be considered in many levels such as 
individual (education level or economic status), relationships (male violence perception of the partner and especially close-relative and the status of social support to women in the process of the violence), community (perspectives of neighbours and colleagues on male violence) and society (inadequate laws and policies against persistence of domestic violence). That is because male violence against women in Turkey is not a problem that can be overcome by only legislation and interventions without analysing and criticising the network of relations and values, which is anchored into the social and cultural context. The problem requires consideration on gender perception, gender inequality and behavioural patterns in gender model context [16]. Since it is effective considering such factors in this study, it is claimed that "community mobilization approach" should be based on and all members of the society should be included in the attempts against violence through engaging (men and boys) who are the subjects of the violence.

\section{3. "Engaging Men and Boys" to Prevent Male Violence against Woman in Turkey}

No matter in which group they are from, women in Turkey from almost all groups are susceptible under violence risk irrespective of their education and economic status, age, marital status or the region they live. From this point of view, inquiring how society will be mobilised engaging men and boys in the attempts against violence has gained importance. In this context, considering the factors leading to male violence against women could give many hints regarding where to begin to prevent violence. For these reasons, based on the studies conducted in Turkey, suggestions are presented on the necessity of engaging men and boys in the attempts against violence in this section.

\subsection{Focusing children (boys) through school-based initiatives and campaigns}

In some studies [17, 18], conducted in Turkey, it is put forward that violence is an acquired and modelled behaviour. One of the researches [17] showed violent men's being subjected to a violent domestic environment in their childhood as a significant factor effecting men resorting to violence in their future lives. In this point, it was stated that modelling his assaulting father who recurrently resort to violence to his mother was an important determiner for the male child to resort to violence as a solution for all kinds of problems [19, 20). In a study [21], aiming at determining the status of violence against women subjected by their teenage children, it was found that teenage children, who were mostly male, resorts to violence against their mothers. Moreover, in this study [21], it was determined that witnessing violence between parents within their families could be effective in their tendency to violence. In addition, it was found that male children subjected to lack of love, self-disrespect, and obstructive behaviour attitude tended more to violence in the future [18]. When it is considered that violence is an acquired behaviour since the childhood years, it can be stated that especially male children should also be a target group for the prevention of violence. In this context, some studies [22, 23] support the idea that school based models should be developed in which some school-based campaigns aiming at preventing violence should be adopted within the curricula and the idea that gender equality curricula that include discussions of gender based violence should be considered. The fact that exercising participatory group education including gender based violence [23] especially about violence in schools is shown to be affective on the behavioural and attitudinal changes among children regarding violence. Additionally, it was determined that school based initiatives, where messages such as the importance of living in a place without sexual assault and necessity to show respect to girls and women, are included in mid school and high school policies, programs and practices, help especially children with avoiding violence [24].

\subsection{Including men who resort to violence in to educative and treating programs}

Societal structure is shown as another important factor for the male violence against women in Turkey. Especially, it is maintained that violence's being accepted as normal by the society, its made to become settled depending on the culture which requires obedience to traditional values and hierarchy under the concept of honour $[25,26]$ are other eminent factors for the male violence against women. As well as the patriarchal values system, which approves male violence against women, unequal and rigid gender roles are also thought to be effective on ignoring the male violence against women [27, 28].

Especially, the thought of protecting the honour of the women is in the centre of male gender since to be a man is considered as inspecting by guarding the virginities of the females within the family, and protecting them from the attacks [29]. Furthermore, cultural acceptance of violence as a manner training instrument could cause 
males to react with violence against their wives in any confrontational disputes in the family [30]. A study [31] demonstrated that violence resorted for the aim of educating was supported more by the males compared to females. Moreover, it was found in this study that the idea that women must be obedient to their husbands in all conditions (even if they are exposed to violence by the men) was agreed by more men compared to women. The ratio of men who agreed on the idea that if women question what their husbands say, husband could resort to violence against women, was calculated more that those of women. In addition, the ratio of men who thought violence as solution for all time was determined to be higher than those of women. The variation between men and women was attributed to social mentality women and men have and the patriarchal structure. It was also maintained in the study that those who resort to violence being mostly the men could be effective on supporting the idea that violence is always necessary [31]. Keeping in mind that patriarchal structure supports the male violence, it is essential to give roles and responsibilities to males primarily with respect to changing societal violence perception through men and enabling a social mentality transformation. As Ferguson et al. [2004] also maintained, programs (educative and treating) aiming at violent partners, sex offenders and child abusers should be prepared in order to prevent especially gender-based violence. Engagement of men resorting to violence against women in these programs should be mainly enforced by criminal justice systems and decrees from the courts encouraging men joining the programs should be issued. Here the aim is not punishing violent men but is to rehabilitate them and to change their beliefs and attitudes inflicting violent behaviours. In this context, it is essential that health, social, and criminal justice agencies should cooperate in order violent men to join these programs and in order victims of violence (women, child, family) to be protected [7].

\subsection{Increasing men's role in family work}

In a study [32], conducted in Turkey, violent behaviour is explained as a result of considering men superior to women economically and physically and placing men as the decision mechanism within the family in patriarchal society. Especially, the fact that men are expected to be the bread winner in the house and, therefore, their being in working life more while women are expected to play domestic roles (such as cooking or looking after a family member) could be effective on the male idea that they could have control on everything in the house including women [31,30]. The fact that jobless women and especially housewives were subjected to violence by their husbands and other people in a study [33] can be shown as findings supporting these considerations. In addition, in some studies, it is shown that along with inadequate income level, low education level causes the emergence of male violence against women most of the time $[33,34]$. However, some recent studies $[3,6,2]$ conducted all across Turkey have shown that increase in the education and economical level falls short in clearing away male violence against women. In one of these studies [2], when the reasons for violence against women were asked to men, it was found that disobedience of women and their being aware of their rights were among the important factors causing male violence against women. In this sense, it can be maintained that in Turkey, even if women's education or economical levels within their families are adequate, they cannot prevent themselves from being subjected to violence. When the fact that mostly jobless housewives are expected to take more domestic roles and responsibilities (caring and nurturing) in most domestic disputes is taken into consideration, to increase men's involvement in family work is required in order to change these expectations. For this purpose, their more involvement in the family work should be supported by social policies and legislation through paternity leave, flexible work and childcare in order fathers to take more responsibilities [35]. Additionally, it can be maintained that mass media education strategies (e.g. programmes that use multimedia such as television, radio and print), which encourage male engagement in the family work more may help provide a mass effect [36].

\subsection{Giving responsibilities to man religious leaders}

There are studies maintaining that also Islam has an effect on male violence effect against women along with patriarchal structure $[37,38,39,26]$. According to Ulus (2005), Islam and patriarchal values, especially based on moral values and cruel customs, could be determiners in the occurrence of the male violence against women. Cayir and Cetin [2011] claim that those who resort to violence, including men, interpret the religious references in a way that they legitimate their malpractices in order to relief themselves from the pangs of conscience stemmed from the harm they give to others. Similar to Cayir and Cetin [2011], in Ozturk [2014], it was found that men who resort to violence used religion in order to find an excuse, in a sense, as a legitimising instrument for the violence against women. This result can be interpreted as the fact that psychological background in the 
root of the violent behaviours of the men who twist religion to legitimate themselves should also be taken into consideration. For this reason, male religious leaders should be called for action against male violence in Turkey. A study [40] on this issue supports that religious leaders have responsibilities in preventing violence and they could educate people within religious institutions and communities, and across faiths, offer spiritual support to those affected by gender-based violence, provide gender-based violence prevention and support programs, commit publicly to addressing gender-based violence and institutionalize support for addressing gender-based violence.

\subsection{Engaging men and boys to prevent early marriage as a form of violence}

Uluocak, Gokulu and Bilir [2014] determined that not only the socio-demographic features of the women but socio-cognitive values system belonging to the social structure was also effective on the partner violence against women. It was found that especially, a socio-cognitive mentality, where men humiliate sexual identity of women and womanhood was effective on the fact that men saw the violence against women legitimate. Similarly, the fact that the risk of being subjected to partner violence was high for women who were exposed to self respect breaking behaviours by their partner was shown as the effects of socio-cognitive factors on partner violence. In another study [31], it was maintained that men's preference to resort to violence against women is very common in patriarchal structures in order to continue their presence and authority on women especially if men had any sexual problems. In this sense, it was pointed out that early age marriages could be in relationship with sexual problems for both men and women and especially with occurrence of sexual violence against women [31]. Early marriage in Turkey is considered as a multi-dimensional violence and abuse form especially for the women and girls [41]. A study [2] has also supported this determination. According to this study, it was established that $26 \%$ of the women in Turkey got married in an early age. It was found that formal and religious marriages were conducted mostly $(94.8 \%)$ and that religious marriages were given priority $(62.7 \%)$ and that this kind of marriage is conducted by an official imam (a civil servant employed by the state) (62.6\%) after a majority of family consent $(46.8 \%)$. The age difference between spouses was found to be 5-9 years $(45.4 \%)$. One of the most eminent outcomes of this study was the establishment of the relationship between early age marriages and male (husband or partner) violence against women. The ratio of physical male violence exposed in the previous 12 months against early-married women was $48 \%$ and sexual violence was $19 \%$. The ratio of being subjected to emotional violence/abuse by men in any time through their lives after getting married early (under the age of 18 ) was $51 \%$. In addition to this, in this study [2], it was found that women with under age marriages were exposed to male violence more when compared to women who got married after 18. In this context, keeping in mind that as well as women relatives (such as mother and elder sisters), men also have immense effect on early age marriages [42], men should take responsibilities in order to prevent early age marriages. As Greene et al. [2015] maintained, "in a patriarchal society, in order to change the status quo, men and boys, as the wielders of power both in the home and the community, must be included in any effort to change social norms, if the effort is to progress and continue beyond the duration of the program. Their understanding of what it means to be a man and of the roles embedded within that understanding-brother, husband, father, partner-needs to shift toward a desire to be caring, respectful, supportive, non-violent, to share decision-making and domestic duties and not to instil intimidation or use control tactics" [43, p.9).

\section{Conclusion}

In conclusion, in order to prevent male violence against women in Turkey and, in this context, to mobilise the community, multi-dimensional, systematic and constant efforts are needed from individual unit to societal level. It can be maintained that engaging men and boys in these endeavours will mean reinforcing women, supporting human rights and contributing to social and economic development.

\section{References}

[1] European Union Agency for Fundamental Rights, Violence against Women: An EU-Wide Survey, Luxembourg: Publications Office of the European Union, 2014.

[2] Republic of Turkey Ministry of Family and Social Policies and Hacettepe University Institute of Population Studies. Türkiye'de Kadına Yönelik Aile Içi Şiddet [Domestic Violence against Women in Turkey], Ankara: Elma Teknik ve Basım Matbaacılık [Elma Technical and Publishing Press], 2015. 
[3] Icon Institute Public Sector, Hacettepe University Institute of Population Studies and BNB Consulting, Türkiye'de Kadına Yönelik Aile İçi Şiddet [Domestic Violence against Women in Turkey], Ankara: Elma Teknik ve Basım Matbaacilık [Elma Technical and Publishing Press], 2009.

[4] S. Uluocak, G. Gokulu, and O. Bilir, "Kadına yönelik şiddetin önlenmesinde stratejik bir başlangıç noktası: Partner şiddeti [A strategic starting point for the elimination of violence against women: Intimate partner violence]". Uluslararası Insan Bilimleri Dergisi [The International Journal of Human Sciences], vol. 11, number 2, pp. 362-387, 2014.

http://dx.doi.org/10.14687/ijhs.v11i2.2942

[5] S.C. Ozyurt, and A. Deveci, "Manisa'da Kırsal Bir Bölgedeki 15-49 Yaş Evli Kadınlarda Depresif Belirti Yaygınlığı ve Aile İçi Şiddetle İlişkisi [The Relationship between Domestic Violence and the Prevalence of Depressive Symptoms in Married Women between 15 and 49 Years of Age in a Rural Area of Manisa, Turkey]", Türk Psikiyatri Dergisi [Turkish Journal of Psychiatry], vol. 21, number 1, pp. 1-7, 2010.

[6] Kamer, The European Instrument for Democracy and Human Rights, Open Society Foundation and İstanbul Faculty of Medicine, (2015). Kadın Hakları İnsan Haklarıdır Projesi [Project on "Women Rights is Human Rights], Available: http://www.aciktoplumvakfi.org.tr/medya/01062015kadinhaklari.pdf.

[7] H. Ferguson, J. Hearn, Ø.G. Holter, L. Jalmert, M. Kimmel, J. Lang, R. Morrel, (2004). Ending gender-based violence: A Call for Global Action to Involve Men. Available: http://www.sida.se/contentassets/008be54196a64ebfb6d8969be7b44626/ending-gender-based-violence-a-call-forglobal-action-to-involve-men_1245.pdf.

[8] J. Pulerwitz, G. Barker, and M. Segundo, (2004). Promoting Healthy Relationships and HIV/STI Prevention for Young Men: Positive Findings from an Intervention Study in Brazil. Available: http://www.popcouncil.org/uploads/pdfs/horizons/brgndrnrmsru.pdf.

[9] T. Abramsky, K. Devries, L. Kiss, J. Nakuti, N. Kyegombe, E. Starmann, B. Cundill, L. Francisco, D. Kaye, T. Musuya, L. Michau, and C. Watts, "Findings from the SASA! Study: A Cluster Randomized Controlled Trial to Assess the Impact of a Community Mobilization Intervention to Prevent Violence against Women and Reduce HIV Risk in Kampala, Uganda', BMC Medicine, vol. 12, number 122, pp. 1-17, 2014.

http://dx.doi.org/10.1186/s12916-014-0122-5

[10] C.M. Graffunder, R. Cline, and K.G. "Lane, Primary Prevention", in Sourcebook on Violence against Women CM, Renzetti, JL Edleson, R. Kennedy-Bergen, Eds. Sage Publication: Los Angeles, London, New Delhi, Singapore, Washington DC, 2011, pp. 209-224.

[11] M. Kim, (2005). The Community Engagement Continuum: Outreach, Mobilization, Organizing and Accountability to Address Violence against Women In Asian and Pasific Islander Communities. Available: http://www.apigbv.org//files/Community.Engagement.Continuum-Report-2005(Rev.2010).pdf.

[12] L. Michau (2005). "Good Practice in Designing a Community-Based Approach to Prevent Domestic Violence, presented at the Expert Group Meeting "Violence against Women: Good Practices in Combating and Eliminating Violence against Women", Vienna, Ustria, May 17-20, pp. 1-17,

[13] L. Michau (2007). "Approaching old problems in new ways: Community mobilisation as a Primary Prevention Strategy to Combat Violence against Women", Gender \& Development, vol. 15, number 1, pp. 95-109.

http://dx.doi.org/10.1080/13552070601179144

[14] L. Heise, "Violence against Women: An Integrated, Ecological Framework", Violence against Women, vol. 4, number 3, pp. 262-290, 1998.

http://dx.doi.org/10.1177/1077801298004003002

[15] L. Michau (2912). "Community mobilization: Preventing Partner Violence by Changing Social Norms", presented at Expert Group Meeting "Prevention of violence against women and girls", Bangkok, Thailand, September 17-20, pp. $1-15$.

[16] S. Uluocak, G. Gokulu, O. Bilir, N. Etizer-Karacik, and D. Ozbay, “Toplumsal Cinsiyet Eşitsizliği ve Kadına Yönelik Şiddet [Gender Inequality and Violence against Women]”, Ankara: Sonçağ Matbaacılık [Sonçağ Press], 2014.

[17] H. Gulec, M. Topaloglu, D. Unsal, and M. Altintas, "Bir Kısır Döngü Olarak Şiddet [Violence as a Vicious Cycle]". Psikiyatride Güncel Yaklaşımlar [Current Approaches in Psychiatry], vol. 4, number 1, pp. 112-137, 2012.

http://dx.doi.org/10.5455/cap.20120408 
[18] F. Kocacik, and M. Caglayandereli, “Ailede Kadına Yönelik Şiddet: Denizli İli Örneği [Domestic violence towards women: Denizli case study]", Uluslararası Insan Bilimleri Dergisi [The International Journal of Human Sciences], vol. 6, number 2, pp. 24-43, 2009.

[19] F. Kocacik, A. Kutlar, and F. Erselcan, "Domestic Violence Against Women: A Field Study in Turkey", The Social Science Journal, vol. 44, number 4, pp. 698-720, 2007.

http://dx.doi.org/10.1016/j.soscij.2007.10.016

[20] I. Vahip, "Evdeki şiddet ve gelişimsel boyutu: Farklı bir açıdan bakış [Domestic violence and its developmental dimension: A view from a different angle]". Türk Psikiyatri Dergisi [Turkish Journal of Psychiatry], vol. 13, number 4, pp. 312-319. 2002.

[21] Z. Bilgin, S. Karaca, and T. Pasinlioglu, "Kadınların Ergen Çocukları Tarafından Şiddete Maruz Bırakılma Durumu ve Otomatik Düşünceler ile İlişkisinin İncelenmesi [Investigation of Relationship with Automatic Thoughts and the Status of Women's Exposure to Violence by Adolescents Children]", Uluslararası Insan Bilimleri Dergisi [The International Journal of Human Sciences], vol. 11, number 1, pp. 965-978, 2014.

http://dx.doi.org/10.14687/ijhs.v11i1.2679

[22] D. Peacock, and G. Barker, "Working with Men and Boys to Prevent Gender-Based Violence: Principles, Lessons, Learned, and Ways Forward", Men and Masculinities, vol. 17, number 5, pp. 578-599, 2014.

http://dx.doi.org/10.1177/1097184X14558240

[23] WHO (World Health Organization), "Engaging Men and Boys in Changing Gender-Based Inequity in Health: Evidence from Programme Interventions", Geneva: Switzerland, 2007.

[24] Men Can Stop Rape. (2011). A Comprehensive Approach: The Strength Campaign. Available: http://www.mencanstoprape.org/A-Comprehensive-Approach-The-Strength-Campaign/.

[25] M. Tezcan, "Türkiye'de Töre Cinayetleri [Honor Crime in Turkey]", 1. Bask1 [1 ${ }^{\text {st }}$ ed.,], Ankara: Naturel Yayınlar1 [Naturel Publishing], 2003.

[26] S. Ulus, “Türkiye'de Cinsiyet Eşitsizliğinin Feodal Örneği Olarak Güldünya Tören ve Kadriye Demirel Töre Cinayetleri Haberlerine Eleştirel Bir Bakış [A Critical View on the Honour Killings News of Güldünya Tören and Kadriye Demirel as Feudal Examples of Gender Inequalities in Turkey]”, İstanbul: Beta Yayınları [Beta Publishing], 2005.

[27] Y. Can, "Türk Ailesinde Aile İçi Şiddetin Kültürel Dinamikleri [The Cultural Dynamics of Domestic Violence on Turkish Family]", Turkish Studies, vol. 9, number 8, pp. 13-19, 2012.

[28] S. Gokulu, and N. Hosta, "Basında Kadına Yönelik Şiddet Haberlerinin Analizi: Hürriyet, Sabah ve Posta Gazeteleri Örneği (2005-2008) [Analysis of Print Media Coverage of Violence Against Women: A Case of The Newspapers of Hurriyet, Sabah and Posta (2005-2008)]", The Journal of Academic Social Science Studies, vol. 6, number 2, pp. 1829-1850, 2013.

[29] S. Okten, "Toplumsal Cinsiyet ve İktidar: Güney Doğu Anadolu Bölgesi'nin Toplumsal Cinsiyet Düzeni Gender and Power: The System of Gender in Southeastern Anatolia]", Uluslararast Sosyal Araştırmalar Dergisi The Journal of International Social Research], vol. 2, number 8, pp. 302-312, 2009.

[30] D. Senol, and S.Yıldız (2007). Bir Kentleşme Sorunu Olarak Gecekondularda Yaşanan Aile İçi Şiddet ve KadınAnkara İli, Çankaya İlçesi, Yıldız Örneği- [Domestic Violence in the Slums as an Urbanisation Problem and WomenAnkara City, Çankaya Town, Yıldız Case], 38. (ICANAS) Uluslararası Asya ve Kuzey Afrika Çalışmaları Kongresi [Icanas 38 International Congress of Asian and North African Studies]. Çevre, Kentleşme Sorunları ve Çözümleri Bildiriler Kitab1 [Problems and Solutions of Environment and Urbanization], Cilt II [Volume II], September 10-15, 2007, pp. 845-855.

[31] D. Senol, and S. Yıldız, "Kadına Yönelik Şiddet Algısı-Kadın ve Erkek Bakış Açılarıyla [Perception of Violence against Women- with Female and Male Points of View]", Ankara: Tarcan Matbaac1lık [Tarcan Press], 2013.

[32] P. Ilkkaracan, L. Gulcur, and C. Arin, "Sicak Yuva Masalı [The Tale of Warm Home]”. İstanbul: Metis Yayınları [Metis Publishing], 1996.

[33] A. Yanık, Z. Hanbaba, S., Soygur, B. Ayalti, and M. Dogan, "Kadına Yönelik Şiddet Davranışlarının Değerlendirilmesi: Türkiye'den Kanıt [Evaluation of Violent Behavior against Women: Evidence from Turkey]", "Electronic Journal of Vocational Colleges", vol. 4, number 4, pp. 104-111, 2014.

[34] M.S. Yavuz, and M. Asırdizer, "Celal Bayar Üniversitesi Tıp Fakültesi Adli Tıp Polikliniği’ne Başvuran Aile İçi Şiddete Maruz Kalmış Kadın Olgularının Analizi [Analyze of Female Cases Which Exposed Domestic Violence and Applied to Forensic Medicine Polyclinic of Medical Faculty of Celal Bayar University]", Adli Tip Dergisi [Journal of Forensic Medicine], vol. 23, number 1, pp. 15-23, 2009. 
[35] B. Pease, "Engaging Men in Men's Violence Prevention: Exploring the Tensions, Dilemmas and Possibilities", Australia: Australian Domestic \& Family Violence Clearinghouse, 2008.

[36] WHO (World Health Organization). (2012). Understanding and Adressing Violence against Women. Available: http://apps.who.int/iris/bitstream/10665/77432/1/WHO RHR 12.36_eng.pdf?ua=1.

[37] C. Cayir, and O. Cetin, "Din ve Şiddet Üzerine Psikolojik Bir Yaklaşım [A Psychological Approach on Religion and Violence]", Dicle Üniversitesi Illahiyat Fakültesi Dergisi [Dicle University Review of Faculty of Divinity], vol. 13, number 1, pp.1-34, 2011.

[38] A.Z. Page, and M. Ince, "Aile İçi Şiddet Konusunda Bir Derleme [A review of Domestic Violence]", Türk Psikoloji Yazılarl [Turkish Psychological Articles], vol. 11, number 22, pp. 81-97, 2008.

[39] E. Ozturk, "Türkiye'de Aile, Şiddet ve Kadın Sığınmaevleri [Turkish Family Violence And Women Shelter Houses]", 21. Yüzyllda Eğitim ve Toplum [Education and Society in 21 st Century], vol. 3, number 7, pp. 39-55, 2014.

[40] B. Herstad, "A Call to Act: Engaging Religious Leaders and Communities in Addressing Gender-based Violence and HIV", Washington, DC: Futures Group, Health Policy Initiative, Task Order 1, 2009.

[41] H. Guner, (2014). Kadına ve Kız Çocuklarına Yönelik Çok Boyutlu Bir İstismar ve Şiddet Türü Olarak Erken/Zorla Evlilikler [Early/Forceful Marriages as Forms of Multi- dimensional abuse and violence against women and girls], Kadının İnsan Hakları Çalıştayı [Women's Human Rights Workshop], March 6, 2014, p. 13-15.

[42] E. Burcu, F. Yildirim, C.S. Sirma, and S.Saniyaman, "Çiçeklerin Kaderi: Türkiye'de Kadınların Erken Evliliği Üzerine Nitel Bir Araştırma [Fate of the Flowers: A Qualitative Research on Early Marriage of Turkish Women]", Bilig Türk Dünyast Sosyal Bilimler Dergisi [Journal of Social Sciences of the Turkish World], vol. 73, pp. 63-98, 2015.

[43] M.E. Greene, S. Perlson, A. Taylor, and G. Lauro, "Engaging Men and Boys to Address the Practice of Child Marriage", Washington, DC: GreeneWorks, 2015. 